TITLE:

\title{
Sprout initiation and growth for three years after cutting in an abandoned secondary forest in Kyoto, Japan
}

\section{AUTHOR(S):}

Imanishi, Ayumi; Morimoto, Junko; Imanishi, Junichi; Shibata, Shozo; Nakanishi, Asami; Osawa, Naoya; Sakai, Shinjiro

\section{CITATION:}

Imanishi, Ayumi ... [et al]. Sprout initiation and growth for three years after cutting in an abandoned secondary forest in Kyoto, Japan. Landscape and Ecological Engineering 2010, 6(2): 325-333

\section{ISSUE DATE:}

2010-07

URL:

http://hdl.handle.net/2433/126700

\section{RIGHT:}

(c) 2010 International Consortium of Landscape and Ecological Engineering and SpringerVerlag Tokyo; This is not the published version. Please cite only the published version.; こ の論文は出版社版でありません。引用の際には出版社版をご確認ご利用ください。 
1 Sprout initiation and growth for three years after cutting in an abandoned secondary forest in Kyoto,

2 Japan

3

4 Ayumi Imanishi ${ }^{1}$, Junko Morimoto ${ }^{2}$, Junichi Imanishi ${ }^{3}$, Shozo Shibata ${ }^{1}$, Asami Nakanishi ${ }^{1}$, Naoya

5 Osawa $^{4}$, Shinjiro Sakai ${ }^{1}$

6

7 1. Field Science Education and Research Center, Kyoto University, Kyoto, Japan

8 2. Graduate School of Agriculture, Hokkaido University, Sapporo, Japan

9 3. Graduate School of Global Environmental Studies, Kyoto University, Kyoto, Japan

10 4. Graduate School of Agriculture, Kyoto University, Kyoto, Japan

12 Corresponding author: Ayumi Imanishi

13 Field Science Education and Research Center, Kyoto University,

14 Oiwake-cho, Sakyo-ku, Kyoto 606-8502, Japan

$15 \quad$ E-mail: makinoa@kais.kyoto-u.ac.jp

16 Tel.: +81-75-753-6434 
1 Abstract

Secondary forests in Japan have been abandoned and the ecosystem has degraded since the high

economic growth period. We carried out cutting in January in three small areas of a long-term abandoned secondary forest and investigated the sprout initiation and growth of woody plants for three years in order to reveal the early stage of sprout regeneration and to understand the sprouting ability and characteristics of each species for effective management. The percentage of sprouted stumps and the number of sprouting shoots was substantially maximized in autumn in the first year.

8 These results suggested that autumn monitoring in the first year after cutting shows the maximum percentage of sprouted stumps and maximum sprout number, when cutting was conducted in the dormant season. For species characteristics, Eurya japonica showed low percentage of sprouted stumps in the lower plot, in which the mean DBH of the species was smaller than in the other plot. and Lyonia ovalifolia var. elliptica had high percentage of sprouted stumps and many sprouts. These species are useful for obtaining sprouting shoots, such as for firewood, but it is difficult to control their sprouting.

17 Keywords: suburban secondary forest, vegetation management, sprout ability 
1<smiles></smiles>

Introduction

Secondary forests in Japan were traditionally managed to obtain firewood, small timber and

(Washitani 2003); however, the methods of obtaining energy and fertilizer have changed since the

high economic growth period, and the value of secondary forests has gradually decreased (Takeuchi

2003). In western Japan, most of these abandoned secondary forests have been changed from pine and deciduous broad-leaved forests to evergreen broad-leaved forests (Morimoto and Morimoto 2003). The National Biodiversity Strategy of Japan, established in 2007, highlights the ecosystem degradation of the rural landscape, including the natural succession of secondary forests as one of three biodiversity crises (Ministry of the Environment 2007).

Recently, suburban secondary forests have been re-evaluated in terms of recreation, environmental education and the conservation of indigenous biodiversity and culture (Hattori et al. 1995). At the site level, vegetation management is conducted by citizen volunteers and local governments (Shigematsu 2002), such as selective logging of evergreen shrubs and bamboos (Yamazaki et al. 2000; Yamase et al. 2005), and clearing underbrush and fallen leaves (Hosogi et al. 2001; Kataoka et al. 2003); however, the number of citizen volunteers has been estimated at about 20,000 and they can manage only $0.03 \%$ of the area of secondary forests in Japan (Tsunekawa 
1 2003). It is necessary to establish efficient adaptive vegetation management methods in secondary

2 forests.

3 For vegetation management of secondary forests, it is essential to understand sprouting because

4 secondary forests had been utilized and maintained by sprouting regeneration at 15-20-year cut

5 intervals. The early stage of regeneration after cutting is an important period because plant species

6 composition and density change dramatically within several years after cutting (Brokaw 1985,

7 Breugel et al. 2006). In the early stage, sprouts generally grow earlier than seedlings and hinder

8 seedlings from growing (Kennard et al. 2002). We reported about seedling regeneration after

9 cutting (Imanishi et al. 2009). In the present study, we will report the early stage of sprout regeneration. 
1

2 (e.g. Mroz et al. 1985; Bellingham et al. 1994).

3

4

5

6

$7 \quad$ Materials and methods

8

9 species.

\section{Study area and experimental design} 1581.8 mm, respectively (Kyoto University Forests 2002).

that influence the sprouting ability and it was reported that sprouting ability differed among species

We investigated the sprouting of woody plants for three years after cutting in order to reveal the early stage of sprout regeneration and to understand the sprouting ability and characteristics of each

All research was conducted at Kamigamo Experimental Station (Field Science, Education and Research Center, Kyoto University, Kyoto) in western Japan $\left(35^{\circ} 04^{\prime} \mathrm{N}, 135^{\circ} 46^{\prime} \mathrm{E}\right)$ (Fig. 1). The bedrock is sandstone and slate, and the soil type is brown forest soil. The annual mean temperature and the annual mean precipitation in the experimental forest from 1971 to 2000 were $14.6^{\circ} \mathrm{C}$ and

Three plots were set along a slope of the experimental forest to study sprouting ability and growth of woody plants under different light environments. The plots (upper, middle and lower) were $30 \times 30 \mathrm{~m}, 20 \times 30 \mathrm{~m}$, and $40 \times 15 \mathrm{~m}$, respectively (Fig. 1). Cuttings were conducted after measuring stem diameters at breast height (DBHs) within these plots.

The area within and around plots became a part of the experimental forest from a national forest 
1

in 1958. There is not an accurate data about the stand condition of the area before 1958. However, it

was reported that the forest neighboring the area was cut clearly around 1925 and after that, dominated by Japanese red pine, Pinus densiflora Sieb. et Zucc. (Akai et al., 1986). Furthermore, it was assumed that the area might be also cut from 1920s to 1940s and the sapling of Hinoki, Chamaecyparis obtusa (Sieb. et Zucc.) Endl, which had naturally generated before cutting, might grow from the result of stem analyses of C. obtusa collected in the plots (Yanagimoto et al., 2000). After 1958, the area had been left under natural conditions. From 1970s, P. densiflora began to be killed by pine wilt disease and most $P$. densiflora died in early 1990s. This area is now dominated by C. obtusa.

To characterize the vegetation in the study area before cutting, we identified all trees taller than $1.3 \mathrm{~m}$ and measured DBHs in the three plots in August 1999. The percentage of total basal area (BA) was calculated for each species in the three plots. The BA of C. obtusa in the upper plot was 40.1 $\mathrm{m}^{2} /$ ha, accounted for $88.7 \%$ of total BA (Table 1). For shrub species, it was dominated by Eurya japonica Thunb. (0.97 $\left.\mathrm{m}^{2} / \mathrm{ha} ; 2.1 \%\right)$ and Rhododendron reticulatum D. Don $\left(0.85 \mathrm{~m}^{2} / \mathrm{ha} ; 1.9 \%\right)$ (Table 1). In the middle plot, the BA of C. obtusa was $37.7 \mathrm{~m}^{2} /$ ha ( $93.5 \%$ ) (Table 1). For shrub species, it was dominated by E. japonica $\left(0.53 \mathrm{~m}^{2} / \mathrm{ha} ; 1.3 \%\right)$ and Camellia japonica L. $\left(0.46 \mathrm{~m}^{2} / \mathrm{ha}\right.$; $1.2 \%)$ (Table 1). In the lower plot, it was dominated by C. obtusa $(19.3 \mathrm{~m} / \mathrm{ha} ; 46.1 \%)$ and Quercus serrata Thunb. ex Murray $\left(12.3 \mathrm{~m}^{2} / \mathrm{ha} ; 29.3 \%\right)$ (Table 1). For shrub species, it was dominated by 
1 Camellia japonica $\left(4.32 \mathrm{~m}^{2} / \mathrm{ha} ; 10.3 \%\right)$ (Table 1$)$.

Almost all of the trees were cut in January 2000 in order to change the dominant species from $C$.

obtusa to $P$. densiflora and/or deciduous broad-leaved trees; however, to improve vegetation recovery after cutting, several mother trees with a DBH greater than $5 \mathrm{~cm}$ were left in each of the experimental plots (Table 1). environment by excluding edges of the plots that were significantly shaded by the surrounding trees so that the survey areas were kept more homogeneous for sprouts. The survey areas were $20 \times 20 \mathrm{~m}$ in the upper and middle plots and $15 \times 25 \mathrm{~m}$ in the lower plot. 8 species, 379 stumps within the survey areas were surveyed (Table 2). September and November 2000, May and November 2001, and May and November 2002. In order to estimate the sprout growth of a stump, the height of the dominant shoot of each stump were measured in May and November 2001 and May and November 2002. 
$1 \times 5$ m quadrats into which each survey area was divided. Hemispherical photographs were taken 1.0

$2 \mathrm{~m}$ above ground level in each quadrat using a Nikon Coolpix 995 with a fish-eye lens.

3 The photographs were analyzed using Gap Light Analyzer ver. 2.0 software (Frazer et al. 1999) to estimate the relative solar radiation from May to November. The radiation parameter to derive above-canopy solar radiation data was applied to modelled.

Statistical analyses

Relative solar radiation was compared among the plots using analysis of variance (ANOVA) and

Tukey's HSD Test. DBHs of parent trees of each species were compared among the plots by the

Mann-Whitney test with Bonferroni correction.

The percentages of sprouted stumps among the plots were tested in each species by the chi-squared test and Haberman's residual analysis. The timing of sprout initiation and death of each species was analyzed in each plot by comparing the numbers of sprouting shoots between survey times using the Wilcoxon signed rank test for matched pairs with Bonferroni correction. Then, the numbers of sprouting shoots in November 2001 were compared by the Mann-Whitney test between the groups that had significantly decreased in 2002 and that had not decreased to confirm if greater number of sprouting shoots in the previous year leads to greater rate of death. Heights of dominant shoots of each species were compared among the plots by the Mann-Whitney test with Bonferroni correction to see if sprout growth was different among the plots. The relationship between number of 
1 sprouting shoots and height of dominant shoots in November 2001 was studied by Spearman's rank

2 correlation analysis.

3 Statistical significance was set at $p<0.05$ and statistical analyses were performed using

4 software (SPSS for Windows, version 13.0J; SPSS Inc. 2004).

5

$6 \quad$ Results

$7 \quad$ Relative solar radiation

8 Relative solar radiation in the upper plot was significantly higher than in the middle and lower

9 plots (Fig. 2). In the middle plot, it was significantly higher than in the lower plot (Fig. 2).

$10 \quad D B H$

For E. japonica, the mean DBH in the lower plot was significantly smaller than in the upper and

middle plots (Table 2). The mean DBH of Camellia japonica was smaller in the middle plot than the lower plot whereas that of Cleyera japonica Thunb. was larger in the middle plot than the lower plot (Table 2). The mean DBH of Lyonia ovalifolia (Wall.) Drude var. elliptica (Sieb. et Zucc.) in the middle plot than the upper plot (Table 2). 
$10 \%$ of Camellia japonica to $100 \%$ of L. ovalifolia var. elliptica. In September 2000, the percentage

2 of sprouted stumps of each species increased to more than $80 \%$, except for E. japonica in the lower

3 plot (Fig. 3). In November 2002, there were some dead stumps that had once sprouted (Fig. 3).

4

$5 \quad$ significantly higher than in the lower plot in November 2002 (Fig. 3).

6

7

8

Number of sprouting shoots had significantly more shoots in November 2001 than other species (Fig. 5).

\section{Height of the dominant shoot}

For E. japonica, the actual percentages of sprouted stumps in the upper and middle plots were

Almost all sprouting shoots initiated during 2000 (Fig. 4). While the two Rhododendron species in the upper plot continued to sprout shoots until May 2001, the number of shoots of Ilex pedunculosa Miq. in the upper plot and Camellia japonica in the lower plot had significantly decreased by May 2001 (Fig. 4). In 2002, the number of shoots of E. japonica in the upper and middle plots, L. ovalifolia var. elliptica, and the two Rhododendron species began to significantly decrease (Fig. 4). Species in which the number of sprouting shoots significantly decreased in 2002

The height of the dominant shoot increased from May 2001 to November 2002, varying from 1.3 times in L. ovalifolia var. elliptica to 2.8 times in Cleyera japonica in the lower plot (Fig. 6). In November 2002, the height of E. japonica in the lower plot was significantly lower than in the upper and middle plots, and the heights of $R$. reticulatum in the upper plot and Cleyera japonica in the 
1 lower plot were significantly lower than in the middle plot (Fig. 6).

2

Rhododendron species in the upper plot in which shoots slightly increased until May 2001 (Fig. 4).

E. japonica and $R$. reticulatum in the upper plot had significantly positive weak correlations

between the number of sprouting shoots and the height of the dominant shoot (Table 3). E. japonica in the middle plot had significantly positive moderate correlation, and I. pedunculosa had significantly positive strong correlation (Table 3 ).

\section{Discussion}

\section{Sprout regeneration for three years after cutting}

More than $80 \%$ of stumps of each species, except E. japonica in the lower plot, had sprouted by September in the first year after cutting (Fig. 3). The number of sprouting shoots was substantially maximized in the first growing season after cutting; the exception being two Shima et al. (1989) also found that sprout initiation finished in the first year after cutting when cutting was conducted during the dormant season. with more shoots showed significantly reduced sprout numbers (Fig. 5). Tanaka (1989) and Rydberg

17 (2000) reported that numerous sprout productions led to a rapid self-thinning process. However, in the present study, it is not clear that the decline of sprout number was caused by competition among 
1 shoots within a stump or competition with the other stumps and seedlings.

1986; Manabe et al. 1991) or maximum (Brown 1994) height of species with numerous sprouts; however, E. japonica, I. pedunculosa and $R$. reticulatum in our study site had a significantly positive correlation between sprout number and the height of dominant shoots (Table 3). One possible reason is that because this study area had sufficient solar radiation, especially in the upper and middle plots (Fig. 2), competition among shoots and/or competition with the other stumps and seedlings might not be severe and vigorous stumps might have many long shoots.

Species characteristics 
1 pedunculosa had an average of 28 sprouts per stump at maximum (Fig. 4). Yamase (2000) reported

2 that L. ovalifolia var. elliptica had many sprouts and the sprouts of both L. ovalifolia var. elliptica

3 and I. pedunculosa grew rapidly. Since in the present study, these species had a high percentage of

4 sprouted stumps (Fig. 3) and grew rapidly (Fig. 6), sprouting regeneration seems an important

5 strategy for their survival in highly managed forests, such as satoyama.

6 Height

For E. japonica and Cleyera japonia, dominant shoots were significantly lower in the lower

8 plot than in the upper and/or middle plots in November 2002 (Fig. 6). Manabe et al. (1991) reported

9 that the mean sprout length of E. japonica was shorter in darker conditions. In the present study,

10 relative solar radiation was significantly lower in the lower plot than in the upper and middle plot

11 (Fig. 2). However, since the mean DBH of E. japonica and Cleyera japonia was significantly growth increment of these species is dependent on the amount of photosynthesis or the reserve nutrient in a stump.

Conclusion 
1 January 2000. The percentage of sprouted stumps and the number of sprouting shoots was

2 substantially maximized in autumn in the first year. The mortality of stumps sprouted by September

32000 was $1.7 \%$, partially due to the high solar radiation in our plots. The number of sprouting

4 shoots began to decrease in the second or third year. These results suggested that monitoring in

5 autumn in the first year after cutting is likely to elucidate the maximum percentage of sprouted

6 stumps and maximum sprout number when cutting was conducted in the dormant season.

$7 \quad$ As species characteristics, E. japonica had dead stumps and showed suppressed growth in the

8 lower plot. Cleyera japonica was also suppressed growth in the lower plot. The sprout ability of

9 these two species was deemed to be influenced by parent tree size because the mean DBH of these

10 species in the lower plot was significantly smaller than in the upper and/or middle plots. However,

11 since relative solar radiation was also significantly lower in the lower plot than in the other plot,

growth increment might be influenced by the amount of photosynthesis as well as the reserve nutrient in a stump. desirable to manage sprouting appropriately based on understanding species characteristics and to monitor sprout regeneration efficiently after cutting with feedback to the management. 
3 Akai T, Nakai I, Okamoto N, Watanabe M (1986) Amenity management and structure of natural regenerated mixture forests of Akamatsu (Pinus densiflora) and Hinoki (Chamaecyparis obtusa) at the urban fringe of Kyoto. Bulletin of the Kyoto University Forests 57: 128-142 (in Japanese with English abstract)

7

8 Babeux P, Mauffette Y (1994) The effects of early and late spring cuts on the sprouting success of red maple (Acer rubrum) in northwestern Quebec. Canadian Journal of Forest Research 24: 785-791 Bellingham PJ, Tanner EVJ, Healey JR (1994) Sprouting trees in Jamaican montane forests, after a

17 Breugel MV, Martínez-Ramos M, Bongers F (2006) Community dynamics during early secondary 
1

2

6 Frazer GW, Canham CD, Lertzman KP (1999) Gap Light Analyzer (GLA) Imaging

Brokaw NVL (1985) Gap-phase regeneration in a tropical forest. Ecology 66(3): 682-687

Brown D (1994) The development of woody vegetation in the first 6 years following clear-cutting of a hardwood forest for a utility right-of-way. Forest Ecology and Management 65: 171-181

software to extract canopy structure and gap light transmission indices from true-colour fisheye photographs, User Manual and Program Documentation, Version 2.0. Simon Fraser University, Burnaby, British Columbia, CANADA, and Institute of Ecosystem Studies, Millbrook.

Forrester F, Bauhus J, Connell M (2003) Competition in thinned Silvertop Ash (Eucalyptus sieberi L. Johnson) stands from early coppice growth. Forest Ecology and Management 174: 459-475

Glitzenstein JS, Harcombe PA (1988) Effects of the December 1983 Tornado on forest vegetation of the Big Thicket, Southeast Texas, U. S. A. Forest Ecology and Management 25: 269-290 
1 conditions of Satoyama (rural forests) and their management. Humans and Nature 6: 1-32 (in

2 Japanese with English abstract)

3

4 Hosogi D, Kuno H, Arai K, Fukada K (2001) Effects of alternation of management to forest floor

5 vegetation and environment of secondary coppice forests in urban area, Tokyo I. Relation between

6 the forest vegetation management method and growth of upper layer trees or forest floor vegetation.

7 Journal of the Japanese Society of Revegetation Technology 27(1): 14-19 (in Japanese with English

8 abstract)

9

10 Imanishi A, Shibata S, Imanishi J, Terai A, Nakanishi A, Sakai S, Osawa N, Morimoto Y (2009)

11 Change of woody-species composition in an early stage of plant succession after cutting in a

suburban secondary forest dominated by Chamaecyparis obtusa. Journal of the Japanese Society of

Revegetation Technology 34(4): 641-648 (in Japanese with English abstract)

Johnson PS (1975) Growth and structural development of red oak sprout clumps. Forest Science 
of parent tree vigor. Canadian Journal of Forest Research 17: 539-544

2

3 Kammesheidt L (1998) The role of tree sprouts in the restoration of stand structure and species

4 diversity in tropical moist forest after slash-and-burn agriculture in Eastern Paraguay. Plant Ecology

5 139: $155-165$

6

$7 \quad$ Katagiri S (1986) Studied on sprout regeneration of Deciduous Broad-leaved trees (I) The growth of

8 sprout shoots during five years after cutting Studies of the San'in Region. Forest resources 2: 27-36

$9 \quad$ (in Japanese)

10

11 Kataoka H, Shima K, Chiba K (2003) The change of forest environments with the conventional

management in broad-leaved secondary forest and its effects on regeneration of tree species. Journal of the Japanese Society of Revegetation Technology 29(1): 297-300 (in Japanese with English abstract) 
1 Kennard DK, Gould K, Putz FE, Fredericksen TS, Morales F (2002) Effect of disturbance intensity

2 on regeneration mechanisms in a tropical dry forest. Forest Ecology and Management 162: 197-208

3

4 Kyoto University Forests (2002) Meteorological observations in the Kyoto University Forests,

$5 \quad$ Kyoto University Forest, Kyoto (in Japanese)

6

7 Malanson GP, Trabaud L (1988) Vigour of post-fire resprouting by Quercus coccifera L., Journal of

8 Ecology 76: 351-365

9

10 Manabe T, Yamamoto S, Chiba K (1991) Stump sprouting of evergreen shrub, Eurya japonica,

11 within a current year of the cutting, Journal of the Japanese Society of Revegetation Technology

16(4): 1-9 (in Japanese with English abstract)

14 Ministry of the Environment (2007) The Third National Biodiversity Strategy of Japan,

17 Morimoto J, Morimoto Y (2003) Satoyama Landscape Transition in the Kansai Area. In: Takeuchi K,

18 Brown RD, Washitani I, Tsunekawa A, Yokohari M (ed) Satoyama -The Traditional Rural 
3 Mroz GD, Frederick DJ, Jurgensen MF (1985) Site and fertilizer effects on northern hardwood

Peterson CJ, Pickett STA (1991) Treefall and resprouting following catastrophic windthrow in an

Putz FE, Brokaw NVL (1989) Sprouting of broken trees on Barro Colorado Island, Panama. Ecology

Rydberg D (2000) Initial sprouting, growth and mortality of European aspen and birch after selective

coppicing in central Sweden. Forest Ecology and Management 130: 27-35 
1

2 fragmented urban forest reserves in present society. Design Issue of Kyusyu institute of technology

3 5: 1-11 (in Japanese with English abstract)

4

5

$7 \quad$ Tokyo: pp 9-16

8

9

Tsunekawa A (2003) Strategic Management of Satoyama Landscapes. In: Takeuchi K, Brown RD,

Washitani I, Tsunekawa A, Yokohari M (ed) Satoyama -The Traditional Rural Landscape of Japan,

Springer, Tokyo: pp 179-191

Uhl C, Clark K, Clark H, Murphy P (1981) Early plant succession after cutting and burning in the 
1 Washitani I (2003) Satoyama Landscapes and Conservation Ecology. In: Takeuchi K, Brown RD,

2 Washitani I, Tsunekawa A, Yokohari M (ed) Satoyama -The Traditional Rural Landscape of Japan,

$3 \quad$ Springer, Tokyo: pp 16-23

4

5 Yamase K (2000) Stump sprouting of main woody species in secondary forest of pine mass-dieback

6 under different thinning intensity. Journal of Japanese Institute of Landscape Architecture 63(5):

$7 \quad$ 465-468 (in Japanese with English abstract)

8

9 Yamase K, Hattori T, Mikami K, Tanaka A (2005) Species richness and species composition of the

10 coppice forests after "Hyogo-Model" vegetation management. Journal of Japanese Institute of

11 Landscape Architecture 68(5): 655-658 (in Japanese with English abstract)

13 Yamazaki H, Aoki K, Hattori T, Takeda Y (2000) Increase of species diversity due to management of

14 vegetation in Satoyama (rural forests). Journal of Japanese Institute of Landscape Architecture 63(5):

481-484 (in Japanese with English abstract)

17 Yanagimoto J, Shibata Y, Hirai T, Hashida R, Nakagawa T, Shibata S (2000)

18 Construction of the volume table and succession for secondary forest of Hinoki in 
1 Kamigamo experimental forest. Bulletin of the Kyoto University Forests 2000: 215-216

2 (in Japanese) 
Table 1 Summary of cutting plots and woody plants pre- and post-cutting

\begin{tabular}{|c|c|c|c|c|c|c|c|}
\hline & & Upper plot & & Middle plot & & Lower plot & \\
\hline & Cutting area $(\mathrm{m} \times \mathrm{m})$ & $30 \times 30$ & & $30 \times 20$ & & $15 \times 40$ & \\
\hline & Slope orientation & $\mathrm{N} 16^{\circ} \mathrm{E}$ & & $\mathrm{N} 46^{\circ} \mathrm{E}$ & & $\mathrm{N} 45^{\circ} \mathrm{E}$ & \\
\hline & Elevation (m) & 203-214 & & $176-190$ & & $144-168$ & \\
\hline & Slope gradient $\left({ }^{\circ}\right)$ & 17.0 & & 28.0 & & 27.0 & \\
\hline \multirow{7}{*}{$\begin{array}{l}\text { Pre- } \\
\text { cutting } \\
\text { (Aug 1999) }\end{array}$} & Species richness & 18 & & 16 & & 21 & \\
\hline & Population density (n/ha) & 7,789 & & 4,717 & & 5,500 & \\
\hline & Woody plants ( $\mathrm{DBH} \geqq 1 \mathrm{~cm})$ & Trees & $\mathrm{BA}\left(\mathrm{m}^{2} / \mathrm{ha}\right)$ & Trees & $\mathrm{BA}\left(\mathrm{m}^{2} / \mathrm{ha}\right)$ & Trees & $\mathrm{BA}\left(\mathrm{m}^{2} / \mathrm{ha}\right)$ \\
\hline & & Chamaecyparis obtusa & 40.12 & Chamaecyparis obtusa & 37.66 & Chamaecyparis obtusa & 19.26 \\
\hline & & Pinus densiflora & 1.53 & Pinus densiflora & 0.93 & Quercus serrata & 12.25 \\
\hline & & Eurya japonica & 0.97 & Eurya japonica & 0.53 & Camellia japonica & 4.32 \\
\hline & & Rhododendron reticulatum & 0.85 & Camellia japonica & 0.46 & Wisteria floribunda & 0.19 \\
\hline \multirow{7}{*}{$\begin{array}{l}\text { Post- } \\
\text { cutting } \\
\text { (Jan 2000) }\end{array}$} & Species richness & 5 & & 2 & & 5 & \\
\hline & Population density (n/ha) & 111 & & 50 & & 400 & \\
\hline & Remnant trees & Species & $\mathrm{n}$ & Species & $\mathrm{n}$ & Species & $\mathrm{n}$ \\
\hline & & Lyonia ovalifolia var. elliptica & 3 & Chamaecyparis obtusa & 2 & Quercus serrata & 13 \\
\hline & & Pinus densiflora & 2 & Pinus densiflora & 1 & Acanthopanax sciadophylloides & 5 \\
\hline & & Chamaecyparis obtusa & 2 & & & Chamaecyparis obtusa & 4 \\
\hline & & Clethra barvinervis & 2 & & & Prunus grayana & 1 \\
\hline
\end{tabular}


Table 2 Number and DBH of stumps of each species before the cutting

\begin{tabular}{|c|c|c|c|c|c|c|c|c|c|c|c|c|}
\hline \multirow{2}{*}{ Species } & \multicolumn{4}{|c|}{ Upper plot } & \multicolumn{4}{|c|}{ Middle plot } & \multicolumn{4}{|c|}{ Lower plot } \\
\hline & $\mathrm{n}$ & & $\mathrm{BH}^{*}$ & & $\mathrm{n}$ & & $\mathrm{BH}^{*}$ & & $\mathrm{n}$ & & $\mathrm{BH}^{*}$ & \\
\hline Eurya japonica & 71 & 2.44 & \pm 0.14 & $\bar{a}$ & 34 & 2.58 & \pm 0.16 & & 28 & 1.53 & \pm 0.19 & \\
\hline Camellia japonica & 7 & 2.75 & \pm 0.87 & & 10 & 2.53 & \pm 0.59 & a & 77 & 4.41 & \pm 0.25 & b \\
\hline Cleyera japonica & - & & - & & 7 & 3.36 & \pm 0.70 & a & 18 & 1.08 & \pm 0.16 & b \\
\hline Pieris japonica & 9 & 1.85 & \pm 0.32 & & - & & - & & - & & - & \\
\hline Ilex pedunculosa & 11 & 6.15 & \pm 0.74 & & - & & - & & - & & - & \\
\hline Lyonia ovalifolia var. elliptica & 16 & 2.99 & \pm 0.31 & a & 7 & 1.81 & \pm 0.62 & b & - & & - & \\
\hline Rhododendron reticulatum & 68 & 1.88 & \pm 0.09 & a & 14 & 2.23 & \pm 0.21 & b & - & & - & \\
\hline Rhododendron macrosepalum & 9 & 1.56 & \pm 0.13 & & - & & - & & - & & - & \\
\hline
\end{tabular}

*: Mean + SE

Different letters indicate significant differences among the plots. 
Table 3 Spearman's correlation cofficients between number of sprouting shoots and height of dominant shoot in

November 2001

\begin{tabular}{|c|c|c|c|}
\hline Species & & $\mathrm{n}$ & $\begin{array}{l}\text { correlation } \\
\text { coefficients }\end{array}$ \\
\hline \multirow{3}{*}{ Eurya japonica } & upper & 71 & $0.30 *$ \\
\hline & middle & 34 & $0.48 * *$ \\
\hline & lower & 28 & -0.05 \\
\hline \multirow[t]{2}{*}{ Rhododendron reticulatum } & upper & 68 & $0.28 *$ \\
\hline & middle & 14 & 0.12 \\
\hline \multirow[t]{2}{*}{ Cleyera japonica } & middle & 7 & 0.74 \\
\hline & lower & 18 & -0.09 \\
\hline Lyonia ovalifolia var. elliptica & & 23 & 0.30 \\
\hline Ilex pedunculosa & & 11 & 0.86 * \\
\hline Camellia japonica & & 93 & 0.10 \\
\hline
\end{tabular}

$\star: p<0.05$

$\star *: p<0.01$ 


\section{Figure captions}

$2 \quad$ Fig. 1 Study area and location of cutting plots

3 Fig. 2 Relative solar radiation from May to November in each plot estimated from

4

5

6

7

8

9

10

hemispherical photos

Error bars show standard errors.

Different letters indicate significant differences among plots.

Fig. 3 Percentage of sprouted stumps of each species in May and September 2000, November 2002

Different letters indicate significant differences among plots.

(u) and (m) indicate upper plot and middle plot, respectively.

(A) and (C) indicate the actual and cumulative percentage of sprouted stumps, respectively.

Fig. 4 Mean number of sprouting shoots per stump during the 3 years after cutting

Error bars show standard errors.

"i" or "d" shows that the number of sprouting shoots significantly increased or decreased compared to the previous survey, respectively.

(u) and (m) indicate upper plot and middle plot, respectively.

Fig. 5 Mean number of sprouting shoots in November 2001 of species that significantly 
decreased or not in 2002, comparison to the previous survey

Error bar shows standard error of the mean.

3

* significant difference.

4 Fig. 6 Height of dominant shoots (cm) from May 2001 to November 2002

Error bars show standard errors.

Different letters indicate significant differences among plots. 
Fig.1

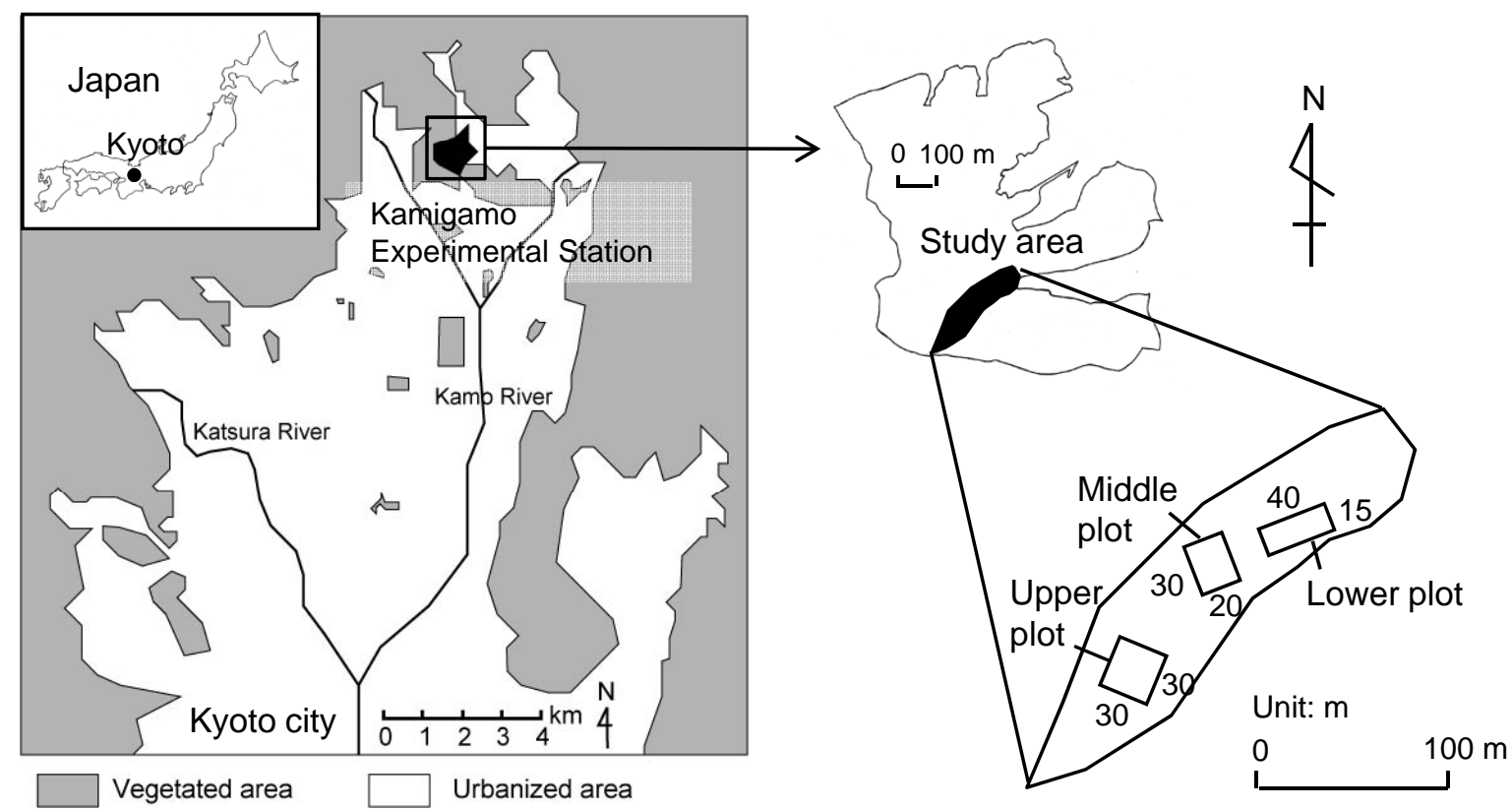


Fig.2

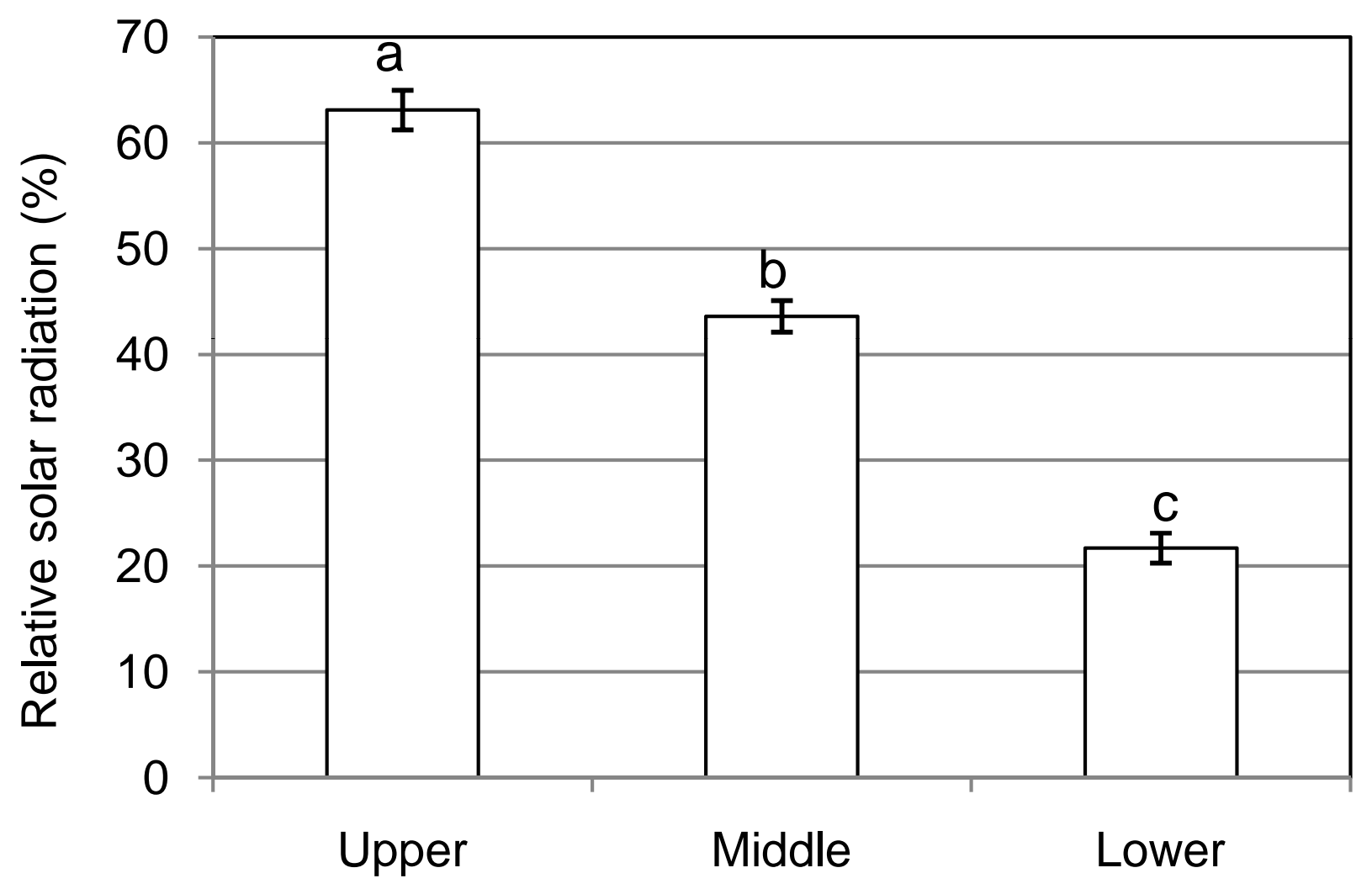




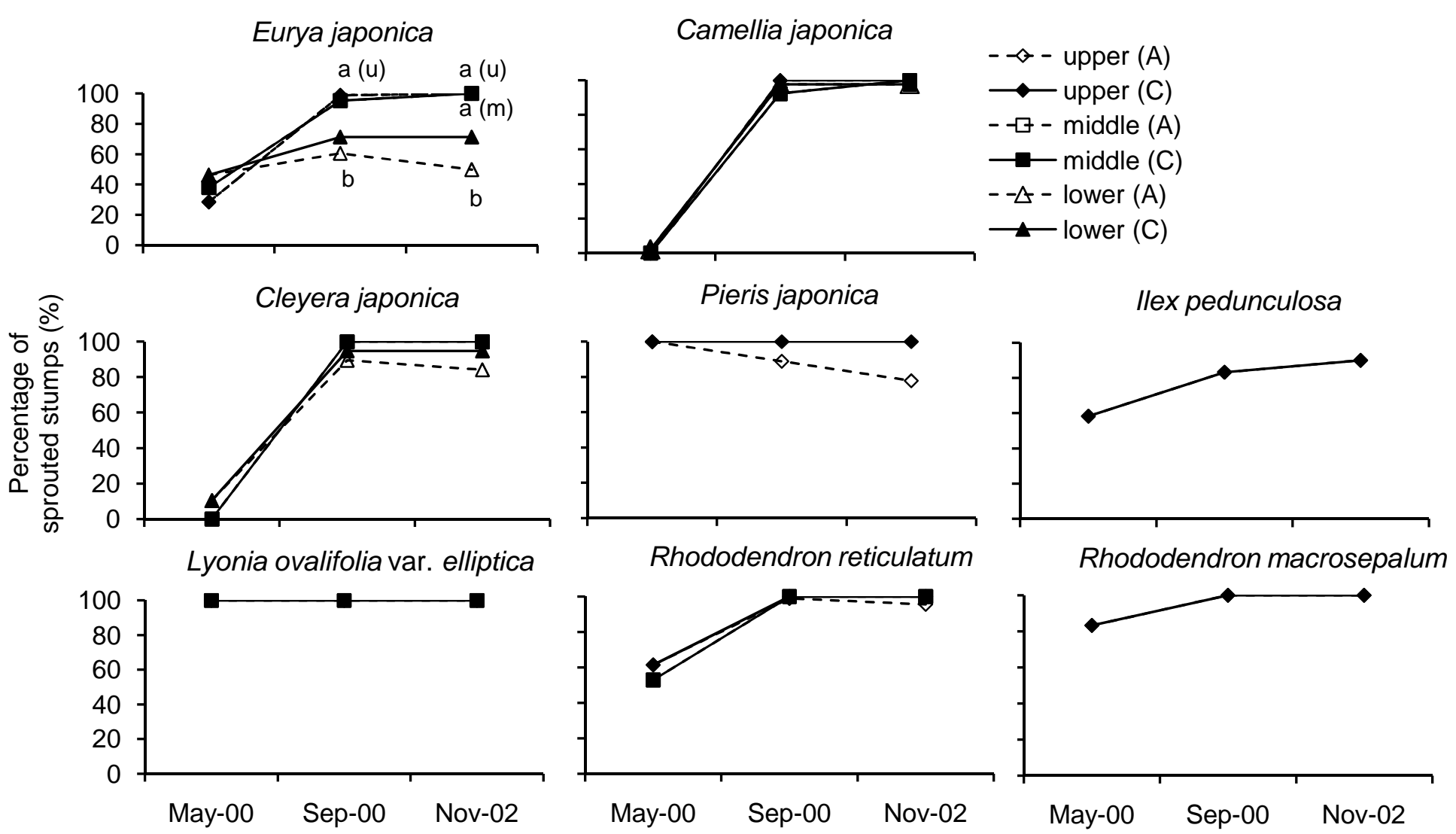



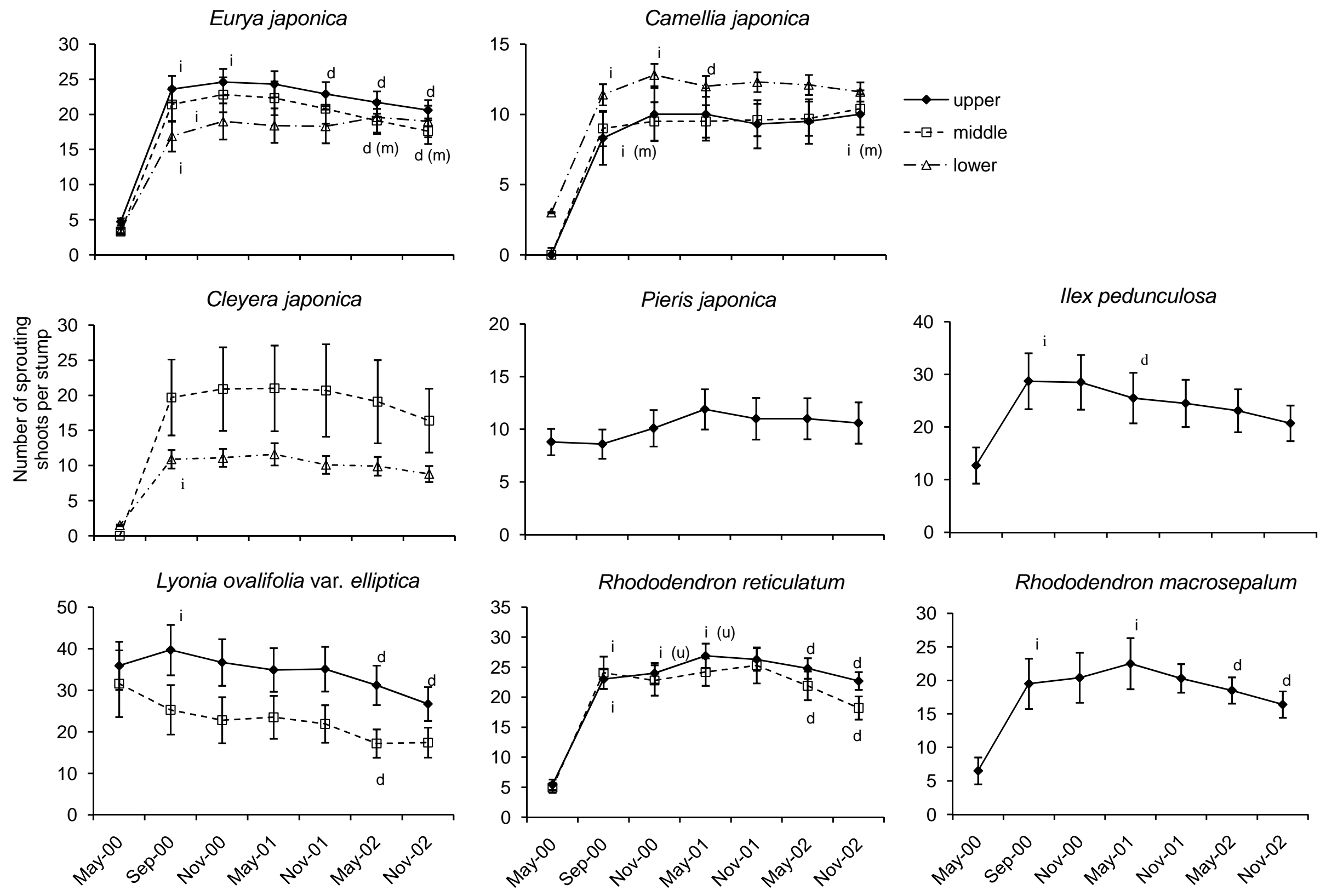
Fig.5

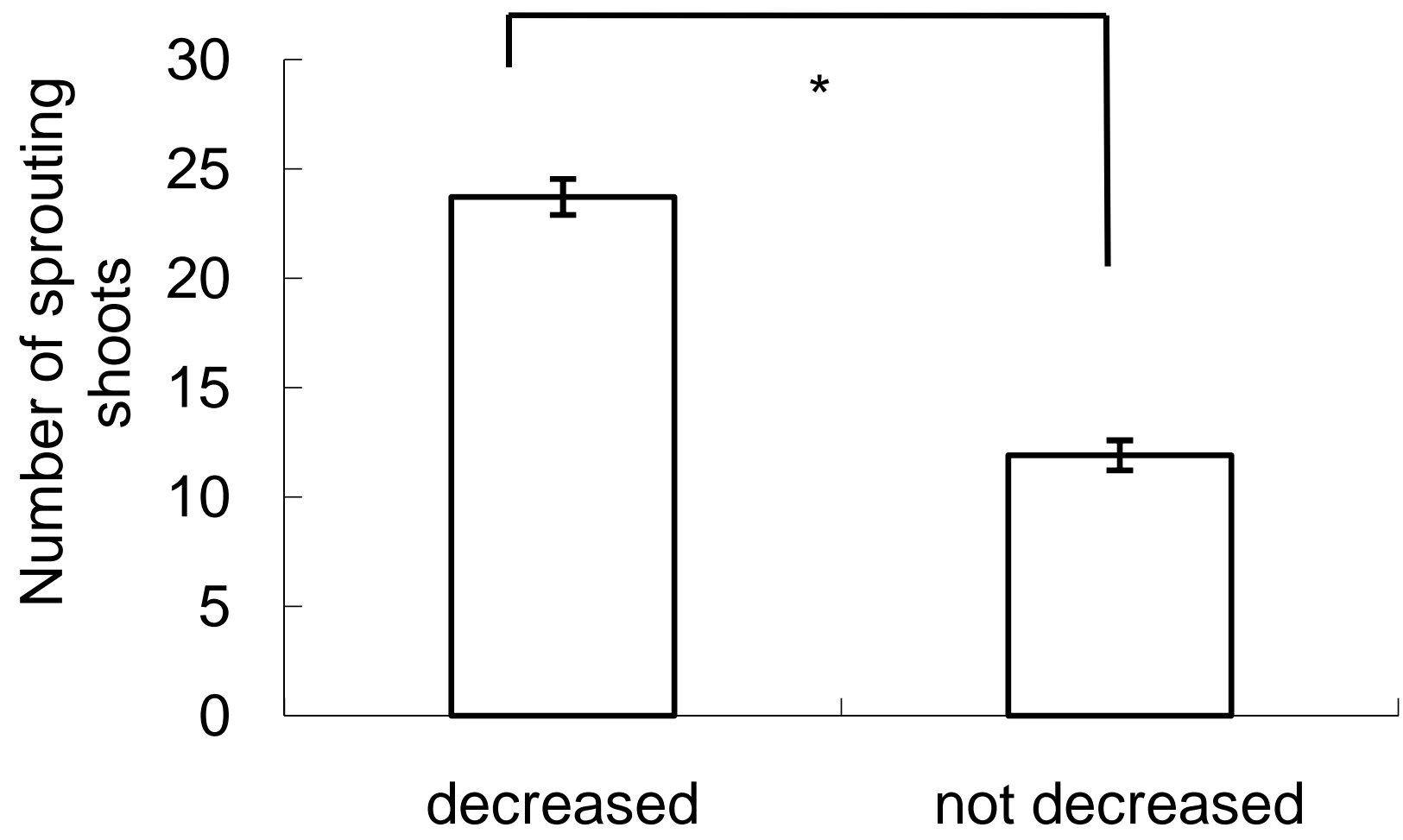



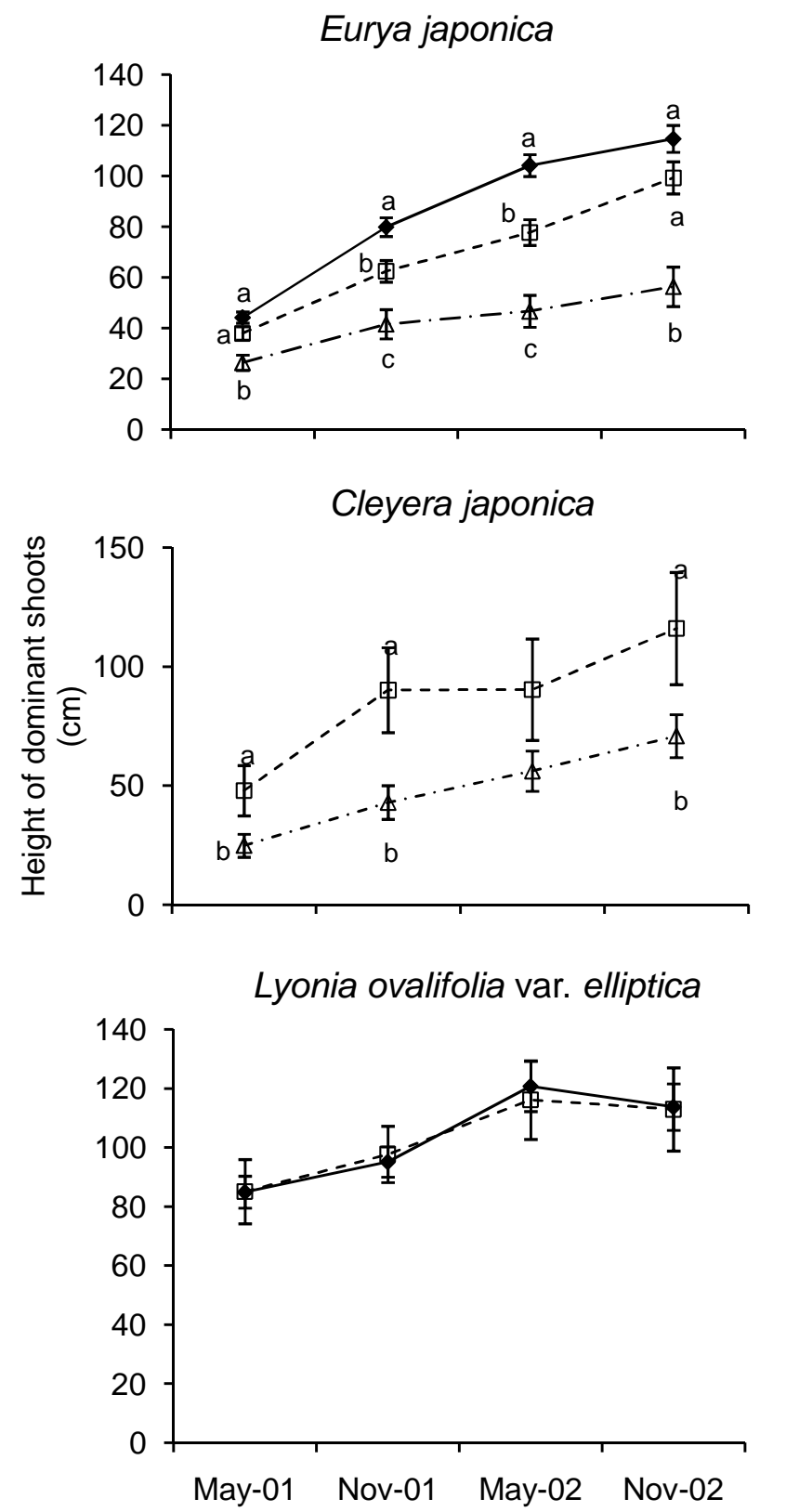
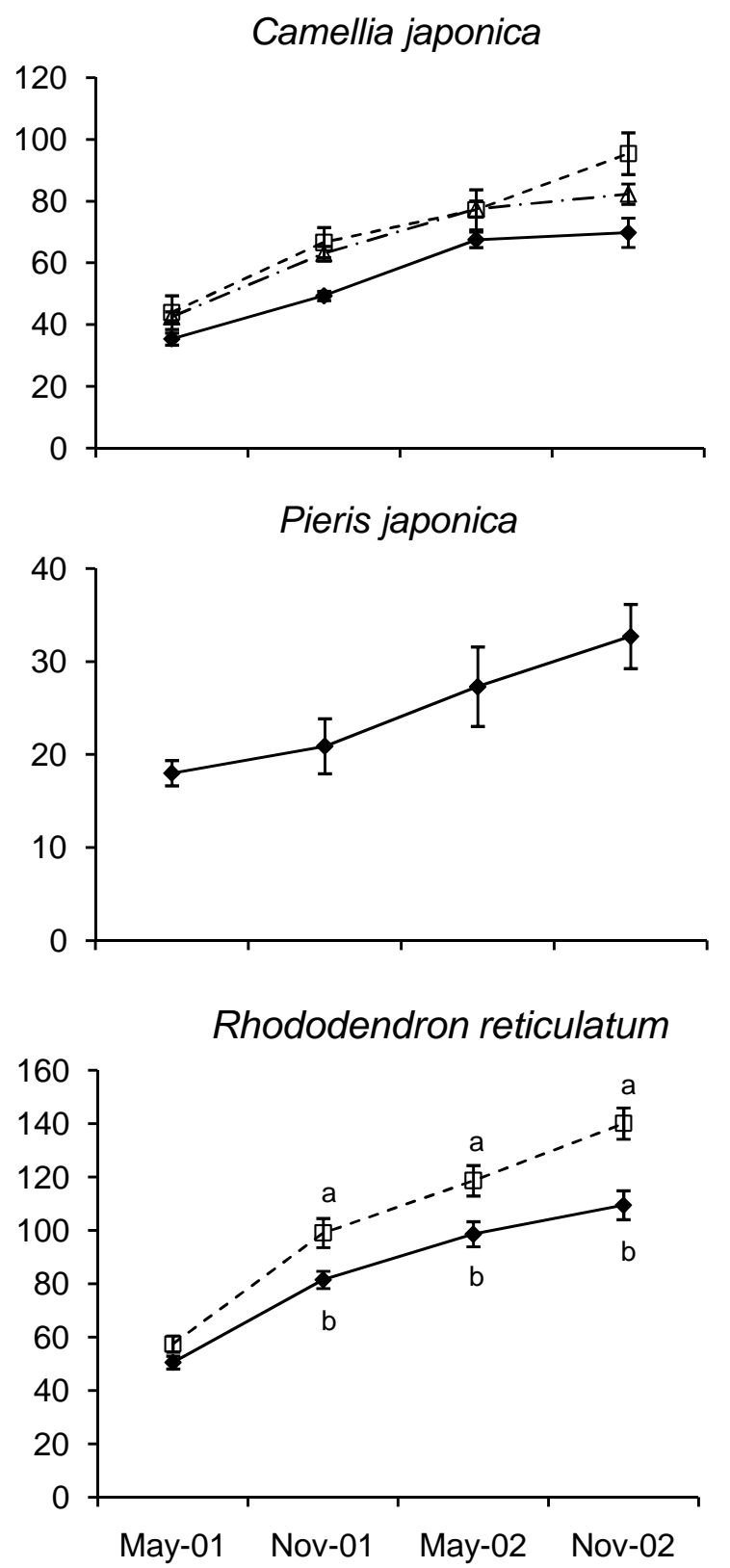
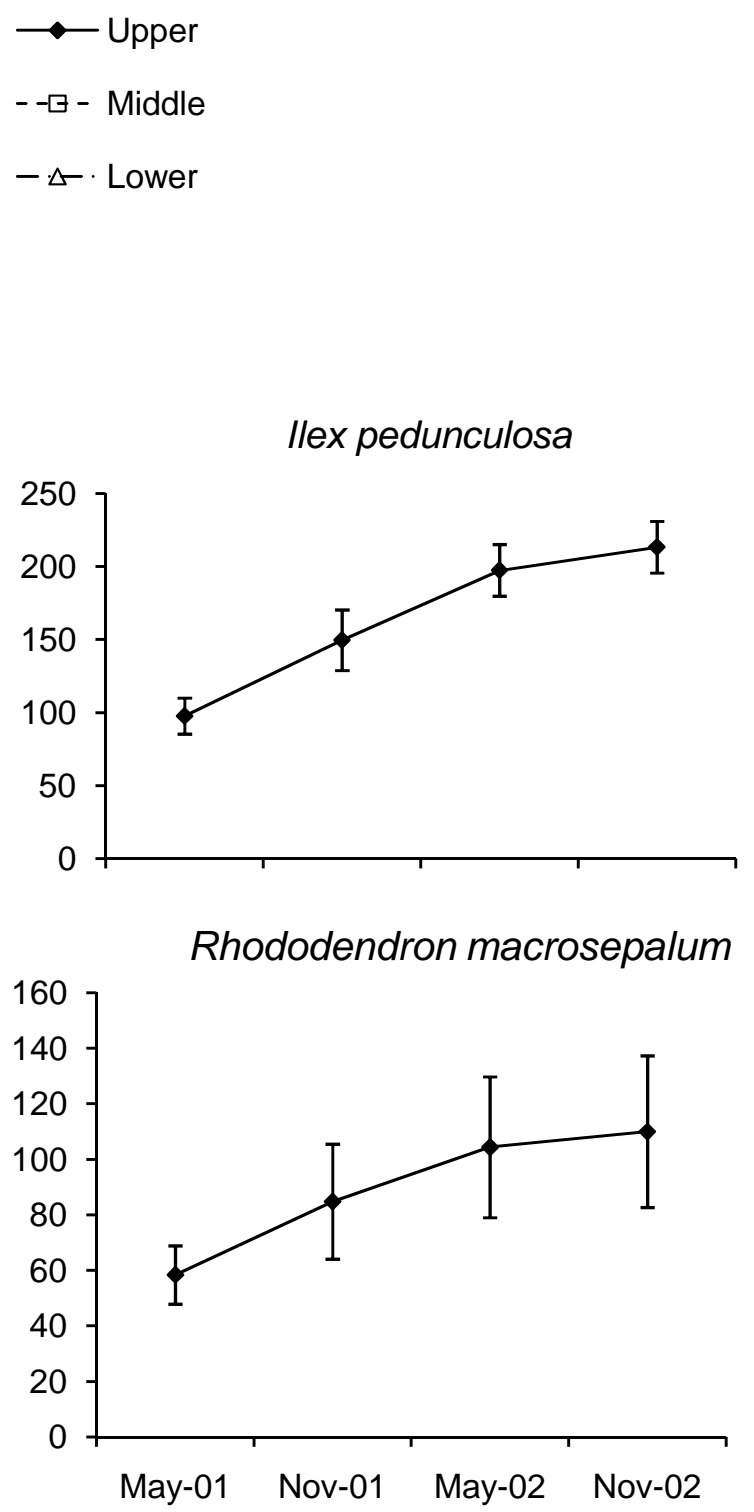